\title{
LIVING BY THE COINS ON THE ROMAN FRONTIER. THE HOARDS AND SINGLE FINDS EVIDENCE AT THE AUXILIARY FORTS IN ROMAN DACIA
}

\begin{abstract}
The present paper is presenting the reader the basic information on the Roman imperial monetary system of the 1st-3rd centuries AD in order to allow him to compare the theory with the field reality. The state of research and the publication of material of the auxiliary forts on the Roman frontier in Dacia are, in fact, key elements when we have to discuss the coin circulation at certain moment and place(s). At the same time, the analysis of numismatic evidence, both hoards and single finds, may offer some hints on the daily life episodes of the Roman soldiers when it was about transactions, coin supply, and moments of turmoil.
\end{abstract}

Keywords: hoards, single coin finds, Roman Dacia, auxiliary forts, frontier

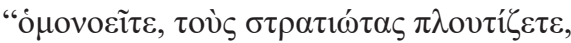

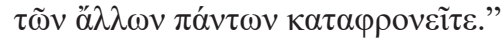
„Be harmonious, enrich the soldiers, and scorn all other men."

(Dio Cassius, 77, 15, 2)

\section{Cristian Găzdac}

Institutul de Arheologie și Istoria Artei

Cluj-Napoca

cgazdac2000@yahoo.co.uk

DOI: $10.14795 /$ j.v5i1.302

ISSN $2360-266 \mathrm{X}$

ISSN-L 2360 - 266X
$\mathbf{T}$

he presumed words of the emperor Septimius Severus (AD 193-211)

on death bed addressed to his sons, Caracalla and Geta, can be taken as the motto of the Roman Imperial financial policy.

In the Roman Empire the army was the biggest money consumer.

In order to count on the army support, was compulsory for the emperors to ensure the military welfare by make the payments on time and frequently raise them, while the pecuniary bonuses (donativae) were quite a common thing. At the end, it had a boomerang effect as many of the emperors ended up being assassinated by their own soldiers or by the praetorian guard, because they were financially unhappy or because a pretender may have bided a higher price for the throne.

Therefore, the military sites - legionary and auxiliary forts - together with their adjacent civilian settlements (canabae legionis for legions; vici militares for the auxiliary units) may serve as excellent sources for numismatic documentation and understanding some aspects of Roman monetary history.

The present paper is trying to offer a comprehensive view on the role of coinage on the Roman frontier by combining general knowledge on Roman monetary system with the numismatic documentation in a case study, the Roman province of Dacia. 


\section{The denominations}

Since the currency reform of Augustus around 20 BC until the one of Diocletian in AD 293 the main denominations of the Roman Empire were: the aureus - gold; the denarius silver; the sestertius, the dupondius, the as - bronze.

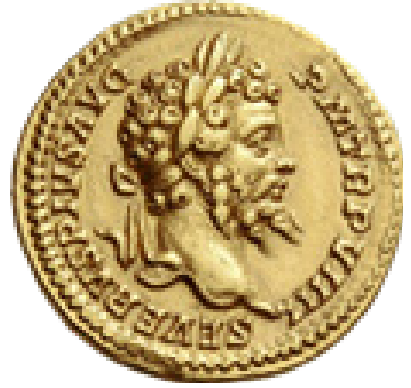

Aureus of Septimius Severus

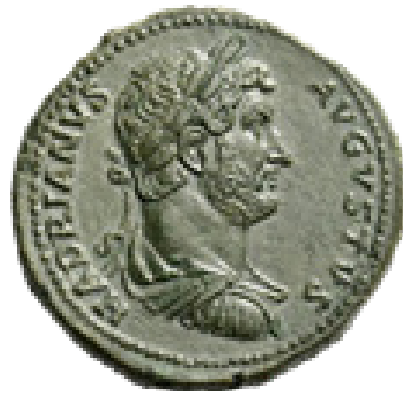

Sestertius of Hadrian

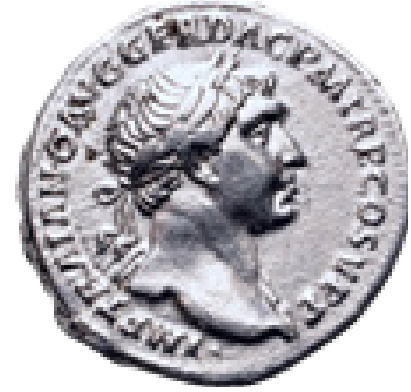

Denarius of Trajan

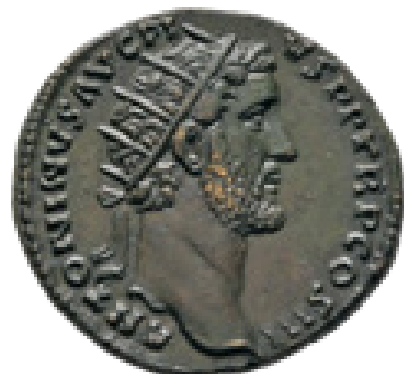

Dupondius of Antoninus Pius

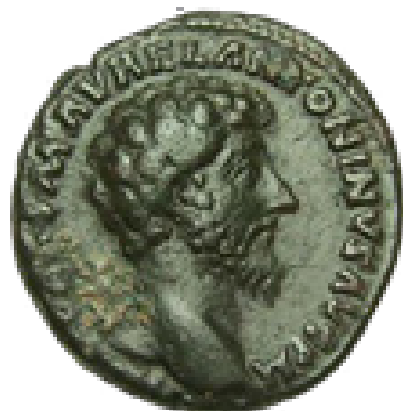

As of Marcus Aurelius

Officially, the exchange rate was: 1 aureus $=25$ denarii $=100$ sestertii $=200$ dupondii $=400$ asses but in practice there many fluctuations

In $\mathrm{AD} 215$, in order to cover the crisis of silver demand on the market, the emperor Marcus Aurelius Severus Antoninus, known as Caracalla, introduced a new coin known as the antoninianus. This coin was overrated to the value of 2 denarii. This denomination will gradually replace the denarius in coin circulation. After mid- $3^{\text {rd }}$ century AD, the antoninianus was, practically, the only silver denomination to be found in circulation the silver contents will go below $1 \%$.

The antoninianus can be considered the denomination that confirms the deep crisis of the Roman Empire after AD 250 .

Beside these official denominations, the Roman forts on the Dacian frontier and not only them provide us with

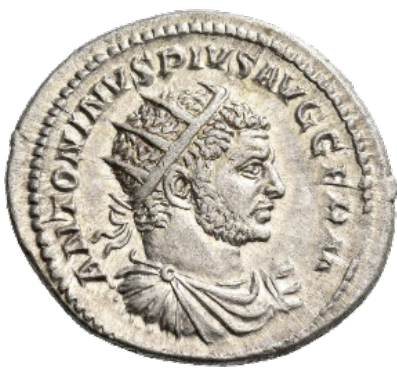

Antoninianus of Caracalla

coins issued by other authorities than the Roman state. These ones are known as the Greek provincial/imperial coins or civic coins. They were minted by some of the Greek cities of the Roman Empire which have receive the right to issue coins. The large majority of these coins were struck in bronze.

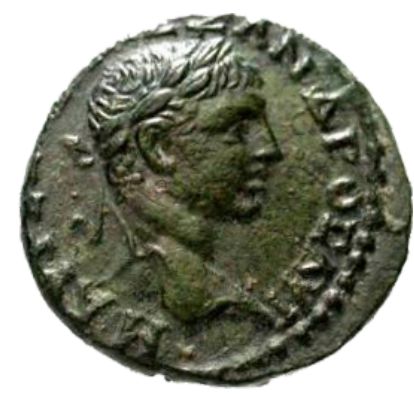

Greek provincial coin of Severus Alexander, Nicaea Bithyniae (Turkey)

\section{HOW WELL PAID WERE THE ROMAN SOLDIERS?}

Like nowadays, to answer this question we must take into account the prices and salaries of those times.

If we agree the soldiers received the same salary according to their rank and position, years of service, then, according to epigraphic sources and papyrology, the soldiers in the auxiliary troops on the garrisoned on the Dacian frontier may have received as the 'basic level - grade 0' between 250 and 300 denarii per annum, the cavalry was even better paid. As previously mentioned, bonuses were often added to the regular payment. ${ }^{1}$

In regard with the prices of the time, probably, the best case for Roman Dacia is a wax tablet, no. XVI, discovered in 1855 in the St. Catherine mining gallery from Roșia Montană (Alburnus Maior). ${ }^{2}$ Although the precise date, the chronological frame can be set to AD 131-169 when the rest of the tablets found in the same environment can be dated. ${ }^{3}$

The wax tablet presents a shopping list to organize a party. Here are some of the prices: 5 lambs $=18$ denarii; 1 piglet $=5$ denarii ${ }^{4}$

I leave it to the reader to decide whether the salary of a soldier from the auxiliary troops was a decent one or not!

\section{THE NUMISMATIC DOCUMENTATION}

As the state, particularly, the emperor, was directly

1 SPEIDEL 1992, 87-106.

2 RUSSU 1975, 243.

3 RUSSU 1975, 175

4 RUSSU 1975, 244, 246 
interested to ensure the army payment one should expect a massive coin frequency on the area of the former military garrisons located on the frontier of Roman Dacia.

And here we come across of the importance of the state of research and publication of an archaeological site (no matter the historical period).

The numismatic and archaeological evidence can reveal opposite situations of the same category of the archaeological site, in this case, the auxiliary forts on the frontier of the same Roman province.

Thus, the largest quantity of single coin finds lost by the Roman soldiers is provided, as expected, by the sites that underwent systematic research followed by a welldocumented publication. At the same time, even in such cases, the numbers highly fluctuate, revealing the size of the excavated area within the forts, as well as the period of use of the forts (e.g. Drobeta on the Danube, which was still in use after the official abandonment of Dacia by. the Roman authorities and army up to the $4^{\text {th }}$ century $\mathrm{AD}^{5}$ ).

At first sight, it is superfluous to mention that the less researched forts produced a small number of coin finds or not at all. However, in some cases, the numismatic documentation is increased by non-scholarly sources: coins found by chance or metal-detecting, which then entered public and private collections, still proofing that even lessor non-researched forts did use coin in transactions.

Based on the above mentioned criteria, I present the numismatic documentation of single coin finds from the border forts in former Roman Dacia (map 1):

\section{SINGLE COIN FINDS}

\section{a) Systematic researched and well-documented forts:}

Drobeta (Drobeta-Turnu Severin): 1,056 coins; welldocumented numismatic documentation, long period of use ( $2^{\text {nd }}-4^{\text {th }}$ centuries AD); $90 \%$ of the fort excavated; ${ }^{6}$

Arcobadara (Ilișua): 456 coins; well-documented numismatic documentation; $80 \%$ of the fort area excavated; ${ }^{7}$

Buciumi: 477 coins; well-documented numismatic documentation; $50 \%$ of the fort area excavated; ${ }^{8}$

Porolissum (Moigrad), 398 coins (the fort on the Pomet Hill); well-documented numismatic documentation; $40 \%$ of the fort area excavated; 9

Slăveni: 165 coins; still in need for a well-documented study; $80 \%$ excavated area; ${ }^{10}$

Samum (Cășeiu): 122 coins; well-documented numismatic documentation; 30\% excavated area; ${ }^{11}$

Tibiscum (Jupa): 113 coins; well-documented numismatic documentation; $10 \%$ excavated area; ${ }^{12}$

Gilău: 109 coins; well-documented numismatic documentation; $20 \%$ excavated area. ${ }^{13}$

\section{b) Partially researched forts}

Romita: 63 coins; basic numismatic documentation;

\footnotetext{
5 GĂZDAC et al. 2015, 18.

6 GĂZDAC et al. 2015, 16-18, 57, 94-146.

7 GĂZDAC/GAIU 2011, 1-4, 29-31, 43-173.

8 GĂZDAC /PRIPON 2012, 11-15, 35, 43-102.

9 GĂZDAC/GUDEA 2006, 15-16, 42, 44-53.

10 TUDOR et al. 2011, 23-41; GĂZDAC 2010, CD_Slăveni.

11 GĂZDAC/ISAC 2007, 12-26, 51, 91-128.

12 ARDEȚ/ARDET 2004, 170; MATEI 2015, 310.

13 GĂZDAC/ISAC 2007, 29-40, 71-79, 149-182.
}

$10 \%$ excavated; ${ }^{14}$

Râșnov, 57 coins; basic numismatic documentation; ${ }^{15}$ $30 \%$ excavated; ${ }^{16}$

Micia (Vețel): 50 coins; basic numismatic documentation, ${ }^{17} 5 \%$ excavated, excavations in progress, new numismatic documentation, unpublished, unseen;

Romula (Reșca), 43 coins; basic numismatic documentation; ${ }^{18}$ the existence of a fort is at a hypothetic level ${ }^{19}$;

Praetorium (Mehadia): 28 coins; basic numismatic documentation; ${ }^{20}$ ? \% excavated; ${ }^{21}$

Hoghiz, 25 coins; basic numismatic documentation; ${ }^{22}$ $5 \%$ excavated; ${ }^{23}$

Olteni, 25 coins; $5 \%$ excavated $;^{24}$ basic numismatic documentation; ${ }^{25}$

Bologa: 21 coins; $20 \%$ excavated area, welldocumented, ${ }^{26}$ excavations in progress, new numismatic material partially seen; ${ }^{27}$

Urluieni, 20 coins; numismatic material welldocumented numismatic documentation, ${ }^{28}$ small forts, $10 \%$ excavated; ${ }^{29}$

Feldioara, 20 coins; basicnumismaticdocumentation; ${ }^{30}$ $5 \%$ excavated, heavily affected by floods; ${ }^{31}$

Jidava (Jidova), 19 coins; 50\% excavated; ${ }^{32}$ basic documented numismatic documentation; ${ }^{33}$

Odorheiul Secuiesc, 18 coins; basic numismatic documentation, uncertain findspot; ${ }^{34}$ unknown location of the fort; ${ }^{35}$

Arutela (Bivolari), 16 coins; numismatic documentation partially published; ${ }^{36}$ 15\% excavated, more than half of the fort destroyed by the river Olt; ${ }^{37}$

Pojejena, 16 coins; basic numismatic documentation; ${ }^{38}$ $10 \%$ excavated (mainly the walls and gates); ${ }^{39}$

Caput Stenarum (Boița), 16 coins; basic numismatic documentation; $;^{40} 3 \%$ excavated area, mainly the defensive system; ${ }^{41}$

14 MATEI/BAJUSZ 1997, 9-10, 169; MARCU 2009, 101-104, GĂZDAC 2010, CD_Romita.

15 MUNTEANU 2017, 240.

16 MARCU 2009, 222-223.

17 MARCU 2009, 144, 288; GĂZDAC 2010, CD_MICIA.

18 GĂZDAC 2010, CD_ROMVLA.

19 MARCU 2009, 228-229, 304.

20 GĂZDAC 2010, CD_PRAETORIVM.

21 The state of publication on this auxiliary fort leads to a blurry situation on the size of the excavated area, MARCU 2009, 143.

22 GĂZDAC 2010, CD_Hoghiz.

23 MARCU 2009, 207;

24 MARCU 2009, 148; 294.

25 GĂZDAC 2010, CD_Olteni.

26 MARCU 2009, 26-36.

27 GĂZDAC 2010, CD_Bologa.

28 GĂZDAC 2010, CD_Urluieni.

29 MARCU 2009, 245-246, 308.

30 GĂZDAC 2010, CD_Feldioara.

31 MARCU 2009, 205-206.

32 MARCU 2009, 196-202, 306.

33 MUNTEANU 2017, 181.

34 GĂZDAC 2010, CD_Odorhei.

35 MARCU 2009, 147-148.

36 GĂZDAC 2010, CD_ARVTELA.

37 MARCU 2009, 181302

38 GĂZDAC 2010, CD_Pojejena.

39 MARCU 2009, 151, 286.

40 MUNTEANU 2017, 172.

41 MARCU 2009, 187-188. 
Comalău, 14 coins; basic numismatic documentation; ${ }^{42}$ $20 \%$ excavated, mainly the defensive system; ${ }^{43}$

Orheiul Bistriței, 13 coins; basic numismatic documentation; ${ }^{44} 3 \%$ excavated area; ${ }^{45}$

Buridava (Stolniceni), 10 coins; numismatic documentation partially seen; $5 \%$ excavated, research in progress;

Inlăceni, 9 coins; basic numismatic documentation; ${ }^{46}$ $15 \%$ mainly the defensive system and two buildings; ${ }^{47}$

Săpata de Jos, 8 coins; basic numismatic documentation; ${ }^{48} 5 \%$ excavated, mainly the defensive system, two forts; ${ }^{49}$

Vărădia, 7 coins; $15 \%$, two forts, mainly the defensive system researched at the fort "Pusta"; 50 basic numismatic documentation; ${ }^{51}$

Brâncovenești, 7 coins; 10\%, ${ }^{52}$ research in progress; basic numismatic documentation; ${ }^{53}$

Sânpaul, 6 coins; basic numismatic documentation; ${ }^{54}$ unresearched; ${ }^{55}$

Enoșești, 6 coins; almost entirely destroyed by the railway; ${ }^{56}$ basic numismatic documentation; ${ }^{57}$

Tihău 5 coins; basic evidence; $;^{58} 5 \%$ excavated area, good magnetometry results; ${ }^{59}$

Teregova, 3 coins; basic evidence; ${ }^{60} \quad 3 \%$ excavated area, the fort highly destroyed by floods; ${ }^{61}$

Boroșneul Mare, 2 coins and some others, unspecified number; poor numismatic documentation; ${ }^{62} 3 \%$ excavated area, mainly the defensive system; ${ }^{63}$

Brețcu, 3 coins; poor numismatic documentation; ${ }^{64}$ $5 \%$ excavated area, mainly the defensive strategy; ${ }^{65}$

Românași, 3 coins; poor numismatic documentation; ${ }^{66}$ $3 \%$ excavated area $^{67}$

Călugăreni, 2; basic evidence; ${ }^{68}$ poor state of research on the fort; 69

Livezile, 1 coin; poor numismatic documentation; ${ }^{70}$ $3 \%$ excavated area, mainly the defensive system $;{ }^{71}$

42 GĂZDAC 2010, CD_Comalau.

43 MARCU 2009, 203, 297.

44 GĂZDAC 2010, CD_Orheiul Bistritei.

45 MARCU 2009, 86, 281.

46 GĂZDAC 2010, CD_Inlaceni.

47 MARCU 2009, 140-143, 293.

48 GĂZDAC 2010, CD_Sapata de Jos.

49 MARCU 2009, 231, 307.

50 MARCU 2009, 174

51 GĂZDAC 2010, CD_Varadia.

52 MARCU 2009, 118-119.

53 GĂZDAC 2010, CD_Brancovenesti.

54 GĂZDAC 2010, CD_Sanpaul.

55 MARCU 2009, 156.

56 MARCU 2009, 205

57 GĂZDAC 2010, CD_Enosesti.

58 GĂZDAC 2010, CD_Tihau.

59 MARCU 2009, 115, 284

60 GĂZDAC 2010, CD_Teregova.

61 MARCU 2009, 157-158.

62 DUDĂU 2006, 98.

63 MARCU 2009, 188-189, 296.

64 DUDĂU 2006, 98-99.

65 MARCU 2009, 193.

66 DUDĂU 2006, 130.

67 TAMBA 1997, 49

68 GĂZDAC 2010, CD_Calugareni.

69 MARCU 2009, 121

70 DUDĂU 2006, 118.

71 PROTASE 2005, 148-149.
Câineni, 1 coin; poor numismatic documentation; $;^{72}$ uncertain location of an auxiliary fort; ${ }^{73}$

Racovița, 1 coin; poor numismatic documentation; ${ }^{74} 10$ $\%$ mainly the defensive system and two buildings; ${ }^{75}$

\section{c) Fort with numismatic documentation known from numismatic collection:}

Cincsor, circa 100 coins; basic numismatic documentation, unknown which of these coins were found on fort's area; ${ }^{76} 3 \%$ excavated area; ${ }^{77}$ poor archaeological material evidence. ${ }^{78}$

These single coin finds were lost during various episodes of daily life. Like nowadays, the largest majority of them are coins of high production, lower value and frequently used in daily transactions, meaning $80 \%$ are bronze denominations (sestertii, dupondii, asses). On the basis of these principled criteria, the next ones are the silver coins (denarii) and rarely the gold coins. At the moment, aurei were discovered at the forts from Bologa (1), Buciumi (1), Porolissum (1), Samum (1), Sânpaul (1), Râșnov (1), Boroșneu Mare (2), Comalău (2), Arutela (1), Vărădia (2), Pojejena (1). ${ }^{79}$

The analysis of coin finds may also serve to identify certain features of a financial behavior on the Roman frontier in Dacia. The single coin finds coming from the forts indicate the dominance of bronze denominations, a consequence of low value money and a higher frequency of use in daily transactions. On the other hand, the coin hoards found within or in the close vicinity of the same forts reveal an opposite situation. Like nowadays, people - in this case prefer to have to save and keep their savings in the most valuable and available coinage. As the Roman gold coin was scarcely used in circulation, the very large majority of hoards consist of silver coins, and very rare some bronze coins, too.

\section{COIN HOARDS}

The coin hoards evidence from the forts on the frontier in Roman Dacia is as follows:

Arcobadara (Ilișua), 33 denarii; Boița, 214 silver coins (unknown denomination); Brețcu, 367 denarii; Câineni, 234 silver coins; Drăgășani, 154 denarii and antoniniani; Gilău, 1,170 silver coins; Ioneștii Govorii, 151 antoniniani; Jidova, 49 denarii; Micia (Vețel), 2,064 denarii and antoniniani; Săpata de Jos, 44 denarii and antoniniani; Sânpaul, 126 bronze coins; Slăveni I, 109 denarii and antoniniani; Slăveni II, 166 antoniniani. $^{80}$ (map 2)

Beside their role as markers of economic and monetary changes, the coin hoards may also be regarded as witnesses to historical events. A large number of hoards found on a certain geographic area with the latest coins issued in the same chronological segment may suggest a common cause

72 DUDĂU 2006, 104

73 MARCU 2009, 196

74 DUDĂU 2006, 128.

75 MARCU 2009, 213-214, 303

76 DUDĂU 2006, 106

77 MARCU 2009

78 ISAC/ISAC 1994, 111.

79 GĂZDAC 2010, CD_Dacia_Site finds; for aurei from Borosneul Mare, DUDĂU 2006, 98.

80 GAZDAC 2010, CD_Dacia_Hoards. 
of non-recovery by the owners.

In support on this argument, in the case of Roman Dacia such a relevant episode is the Carpic war (AD 246248) during the reign of the emperor Philip I (AD 244249). According to the ancient literary sources this war was causing serious damages as the emperor came in person in Dacia to end it. ${ }^{81}$

This moment of turmoil seems to be confirmed by a large number of hoards ending with coins of Gordian III (AD 238-244) and Philip I (AD 244-249) while the area of discovery is mainly concentrated on the frontier zone from the Olt River. (map 3)

\section{COUNTERFEITING}

Another specific aspect revealed by the coin finds from the frontier forts in Dacia and not only them is the large number of counterfeited pieces.

The coin finds indicate that the most frequently used method to fake a coin was plating. A core of common metal (e.g. copper) was wrapped in a silver foil.

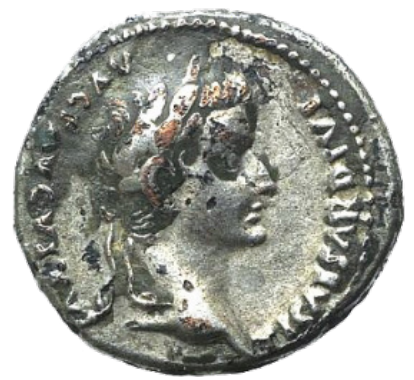

Plated denarius bearing the portrait of emperor Tiberius

Another technique was casting. At the moment, it seems to have been used more for bronze coins. A genuine coin was impregnated/stamped in soft clay. After the clay dried out, the hot metal was poured resulted in a cast coin. After the cooling of metal, the moulds were broken and the edges were cut or rasped away.

The large quantity of counterfeited coins found especially at the forts - in some case over $40 \%$ for silver

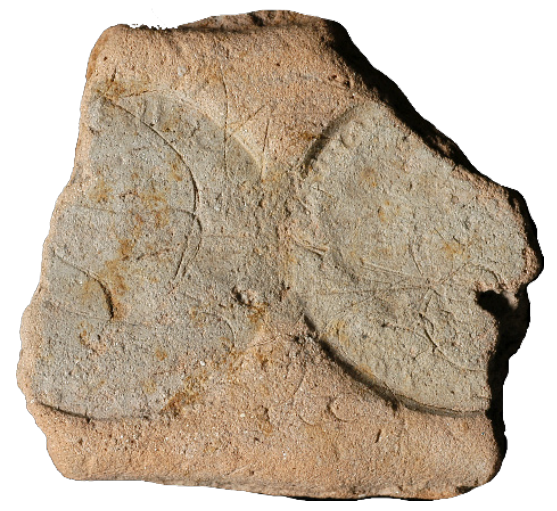

Clay mould fragment to cast coins (Carnuntum) ${ }^{82}$

81 PISO 1974, 301-309.

82 GĂZDAC/HUMER 2008, 46, fig. 7.

83 GĂZDAC/HUMER 2008, 44, fig. 4.

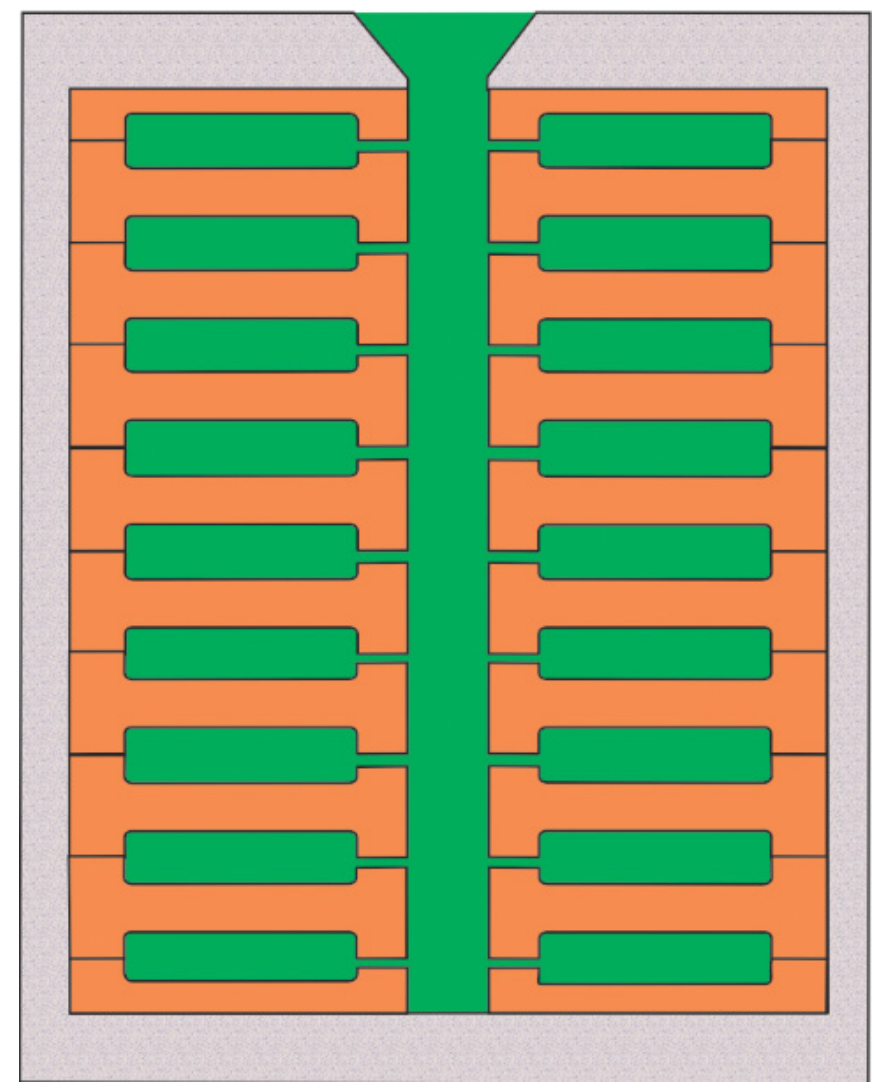

A technological line to cast coins
denominations uggest a massive phenor noticed in many other parts of the empire. ${ }^{85}$

A solid argument on this line, for the province of Dacia is provided by the so-called hoard Apulum VI, found in, nowadays, Alba Iulia, only $1 \mathrm{~km}$ from the wall of the fort garrisoning the $13^{\text {th }}$ Gemina legion. ${ }^{86}$ In fact, it has been demonstrated that this 'hoard' consists of 232 cast copper coins that were supposed to pass as silver denarii. The far too high content of copper led to the rejection of this hoard right at the place or near the place of production.

The theory that such counterfeited coins were produced with the permission of the military authority seems to be supported by the discovery of a spoilt cast coin in the south-west tower of the porta praetoria of the auxiliary fort from Ilișua.

In all cases when a large number of plated silver coins were found the largest majority of them bearing the effigies from the time of Septimius Severus and Caracalla (AD 193217). A period marked by the increase of military payments and the crisis of silver. ${ }^{87}$

One last aspect revealed by the numismatic documentation is that the frequency of coin finds can be an argument for both the beginning and the end of human presence in a place.

In the case of Dacia, the Roman conquest in the time of emperor Trajan (AD 98-117) meant the incoming of a large number of population, both military and civilians. New settlements, civilian and military, were established implying a large number of constructions. All these aspects 84 GĂZDAC 2009, 1490.

85 GĂZDAC 2009, 1496.

86 GĂZDAC/OARGĂ/ALFÖLDY-GĂZDAC 2015, 27.

87 SPEIDEL 1992, 106; HAIM/PONTING 2003, 26. 

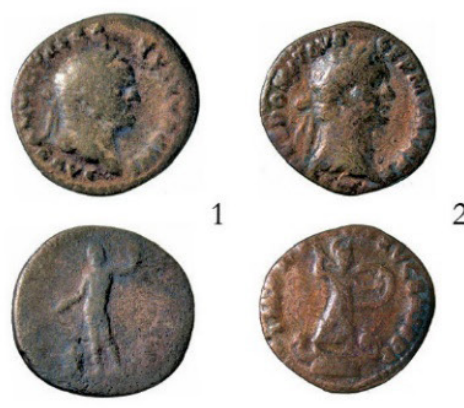

2

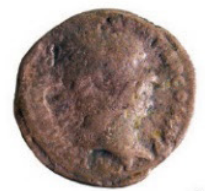

3
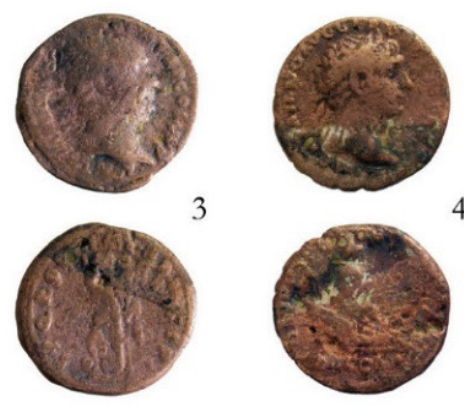

4
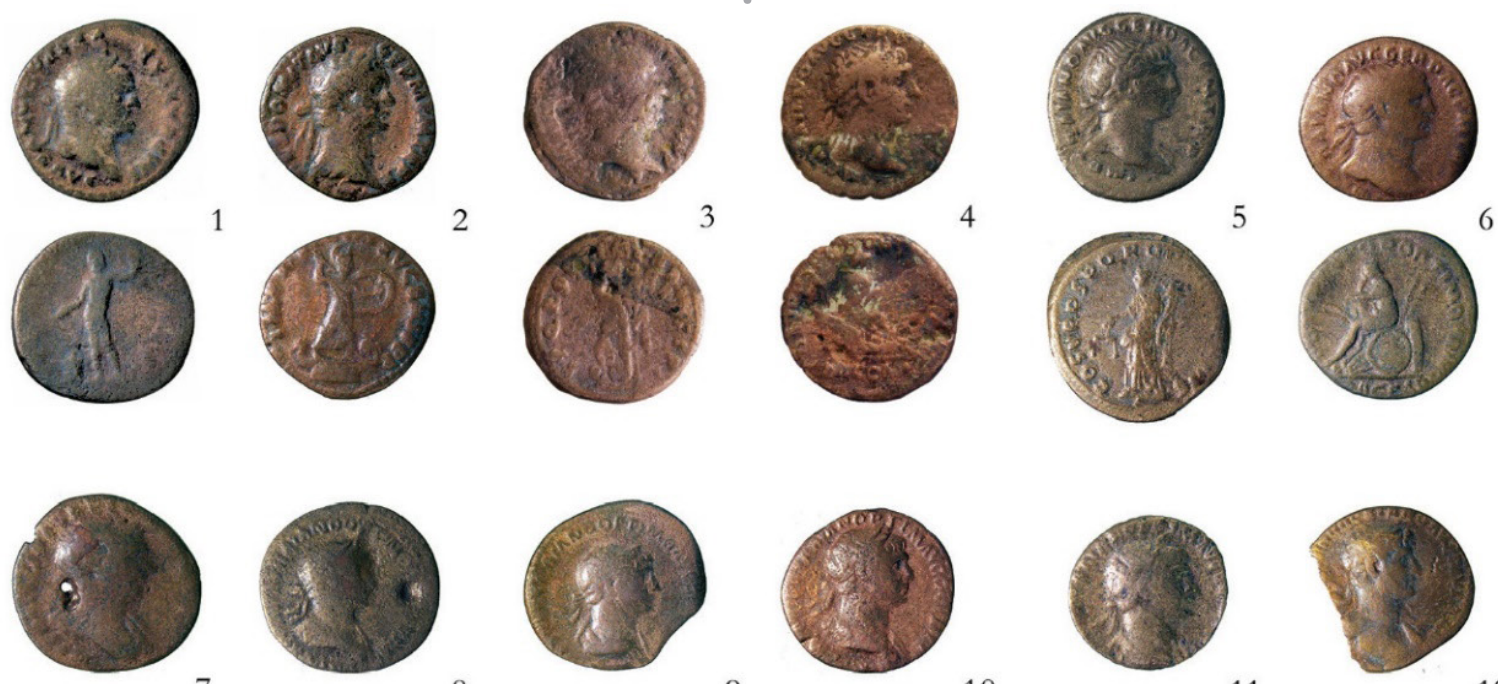

9

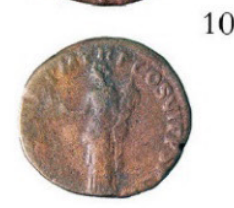

10
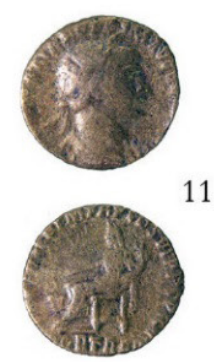

11
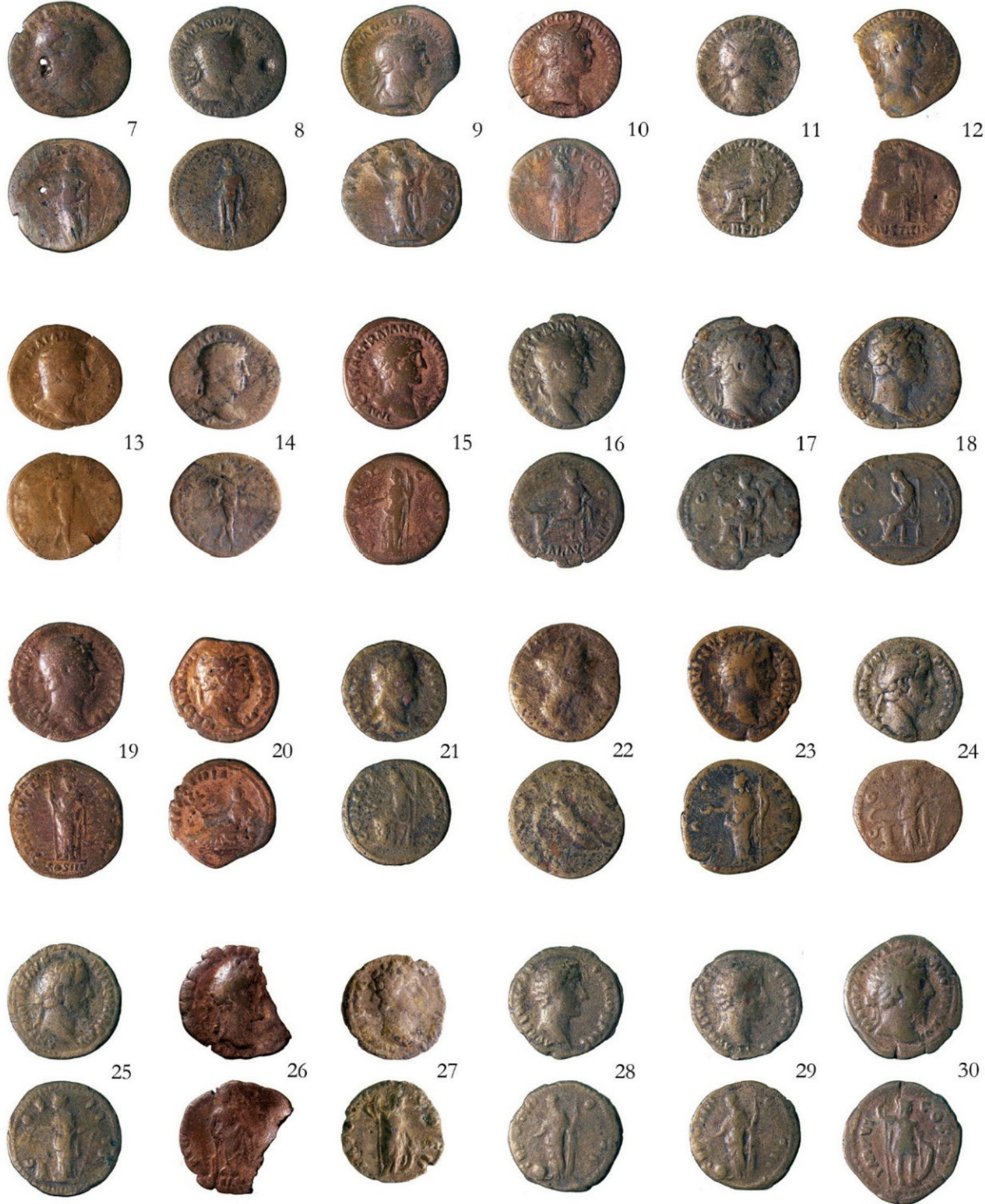

29
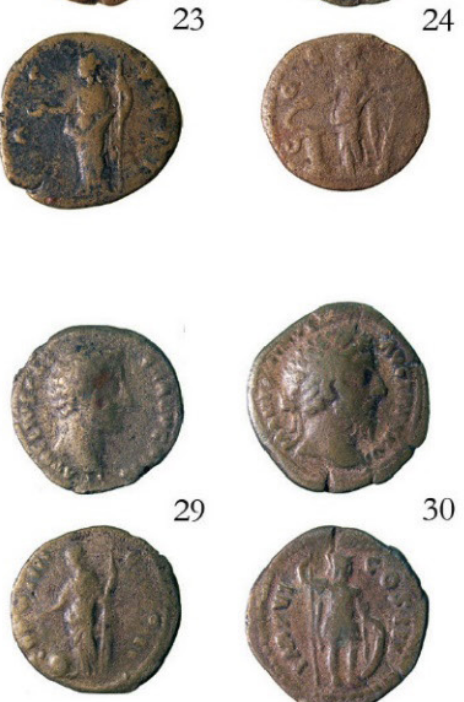

Sample of copper cast coins with bit of silver, which were supposed to pass as silver denarii in the scrap hoard found in the vicinity of the legionary fortress at Alba Iulia. ${ }^{88}$

88 GĂZDAC/OARGĂ/ALFÖLDY-GĂZDAC 2015, 103. 


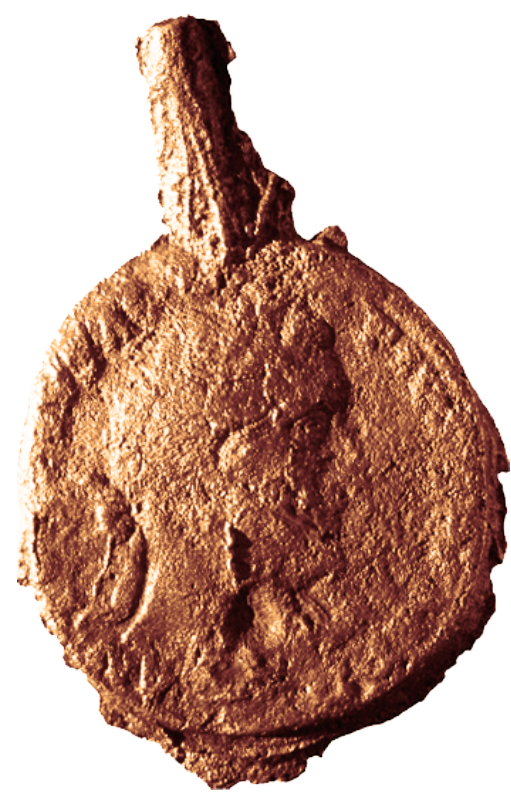

The spoilt-coin from the fort of Ilișua ${ }^{89}$ requested a large sum of money for services and payments. The numismatic and archaeological evidences, both confirm that this moment of the province foundation was marked by a far higher number of Trajan's coins found in Dacia in comparison with the previous and later emperors, as well as with other provinces. ${ }^{90}$

The abandonment of the province by the Roman army in the second half of the $3^{\text {rd }}$ century AD is marked by different stages. The largest urban sites in Dacia, and at the same time, with a well-documented numismatic documentation, such as Apulum, Ulpia Traiana Sarmizegetusa, Drobeta Porolissum, Tibiscum reveal a strong decrease of coin finds for the reign of Gallienus (AD 260-268). However, the border forts indicate a different situation. The latest coin to be found at most of them was minted in the time of the emperor Philip I (AD 244-249). ${ }^{91}$

Still, one should not forget a common methodological aspect for many of the ancient artefacts. The coin could have stood in circulation much longer that the emperor who issued it.

\section{ACKNOWLEDGMENTS}

This work was supported by a grant of the Romanian National Authority for Scientific Research, UEFISCDI, project number PN-III-P4-ID-PCE-2016-0021

\section{REFERENCES}

\section{ARDET,ARDET 2004}

Ardeț, A./Ardeț, L.C.: Tibiscum. Așezările romane (ClujNapoca: NereaMia Napocae).

DUDĂU 2006

Dudău, O.: Circulația monetară în castrele de trupe auxiliare din provincia Dacia. (Timișoara: Graphite).

GĂZDAC 2008

Găzdac, C.: The coinage and the Roman conquest of Dacia. A comparative study of the sites: Ulpia Traiana, Porolissum, Carnuntum, Ovilava, Poetovio. In: Spinei, V./ Munteanu, L. (eds.): Miscellanea numismatica antiquitatis: in honorem septagenarii magistri Virgilii Mihăilescu-Bîrliba oblate (Bucureşti: Editura Academiei). 69-80.

GĂZDAC 2009

Găzdac, C.: The distribution of silver counterfeited coins in the forts from Roman Dacia. Fraud or monetary policy? In: Morillo, Á./Hanel, N./Martín, E. (eds.): XXth International Congress of Roman Frontier Studies, Leon, September 2006 [Gladius 13]. 1487-1498.

\section{GĂZDAC 2010}

89 GĂZDAC/GAIU 2011,$15 ; 243$, no. 3 .

90 GĂZDAC 2008, 79-80.

91 GĂZDAC 2010, CD_Dacia_Site finds
Găzdac, C.: Monetary circulation in Dacia and the provinces from the Middle and Lower Danube from Trajan to Constantine I (AD 106-337). [Coins from Roman Sites and Collections of Roman Coins from Romania 7] (Cluj-Napoca: Mega Publishing House).

GĂZDAC et al. 2015

Găzdac, C./ Alföldy-Găzdac, Á./ Neagoe, M./ Neagoe, O.: Drobeta. The Never Abandoned City of Roman Dacia. [Coins from Roman Sites and Collections of Roman Coins from Romania 9] (Cluj-Napoca: Mega Publishing House).

GĂZDAC/GAIU 2011

Găzdac, C./ Gaiu, C.: Arcobadara (Ilişua). [Coins from Roman Sites and Collections of Roman Coins from Romania 6] (Cluj-Napoca: Mega Publishing House).

GĂZDAC/HUMER 2008

Găzdac, C./Humer, F.: Coin moulds that have produced the so-called "Limesfalsa" at Carnuntum. Carnuntum Jahrbuch. 41-50.

GĂZDAC/OARGĂ/ALFÖLDY-GĂZDAC 2015

Găzdac, C./ Oargă, O./ Alföldy-Găzdac, Á.: It Was Supposed to Be Silver! The Scrap Coin 'Hoard' Apulum VI [Coins from Roman Sites and Collections of Roman Coins from Romania 5/2] (Cluj-Napoca: Mega Publishing House).

HAIM/PONTING 2003

Gitler, H./Ponting, M.: The Silver Coinage of Septimius Severus and His Family, (193-211 AD). A Study of the Chemical Composition of the Roman and Eastern Issues [Glaux 16] (Milano: Ennerre).

ISAC/ISAC 1994

Isac, D./Isac, A.: Noi date arheologice despre castrul roman de la Cincșor (jud. Brașov). Ephemeris Napocensis 4. 103112.

MARCU 2009

Marcu, F.: Organizarea internă a castrelor din Dacia (ClujNapoca: Mega).

\section{MATEI 2015}

Matei, C.: Circulaţia monetară romană pe teritoriul anticului Tibiscum (sec. I-IV p.Chr.). vol. I-II (Szeged: JATEPress).

MATEI/BAJUSZ 1997

Matei, Al./Bajusz, I.: Castrul roman de la Romita - Certiae (Zalău: Ardealul).

\section{MUNTEANU 2017}

Munteanu, L.: Moneda în așezările Daciei romane (Iași: PISO 1974 Editura Universității "Alexandru Ioan Cuza").

Piso, I.: Războiul lui Philippus cu carpi. In: In memoriam Constantini Daicoviciu (Cluj: Dacia). 301-309.

\section{PROTASE 2005}

Protase, D.: Un castru roman de pământ la Livezile, pe granița de nord a Daciei. In: Orizonturi daco-romane. Vol. II (Cluj-Napoca: Napoca Star).

\section{RUSSU 1975}

Russu, I.I.: Inscripţiile Daciei Romane. Vol. I. (București: Editura Academiei Republicii Socialiste România).

\section{SPEIDEL 1992}

Speidel, M.A.: Roman Army Pay Scales. Journal of Roman Studies 82. 87-106.

\section{TAMBA 1997}

Tamba, D.: Castrul roman de la Românași-Largiana (Zalău: Ardealul).

TUDOR et al. 2011

Tudor, D./Popilian, Gh./Gudea, N./Bondoc, D.: Castrul roman de la Slăveni. Încercare de monografie arheologică (ClujNapoca: Mega). 


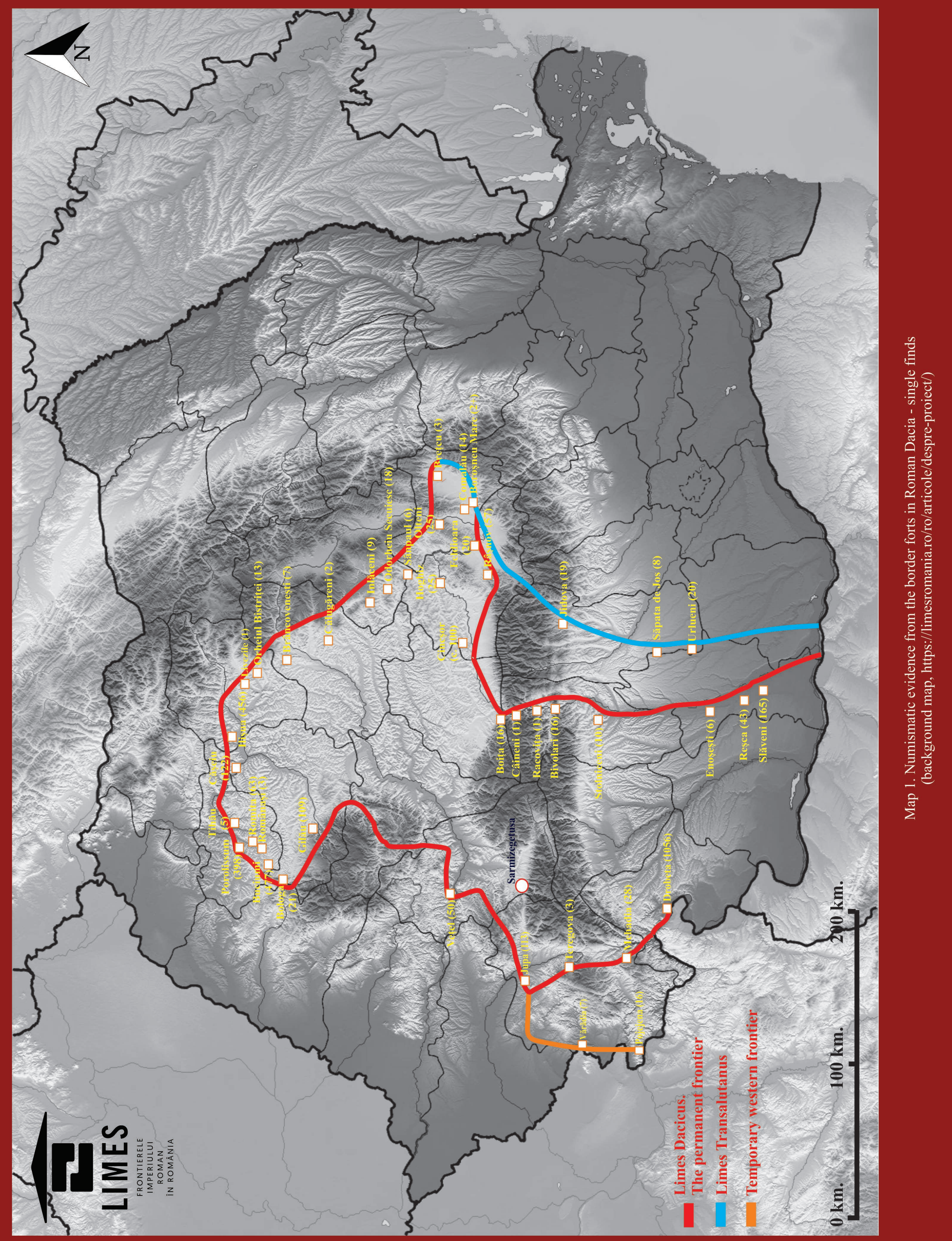




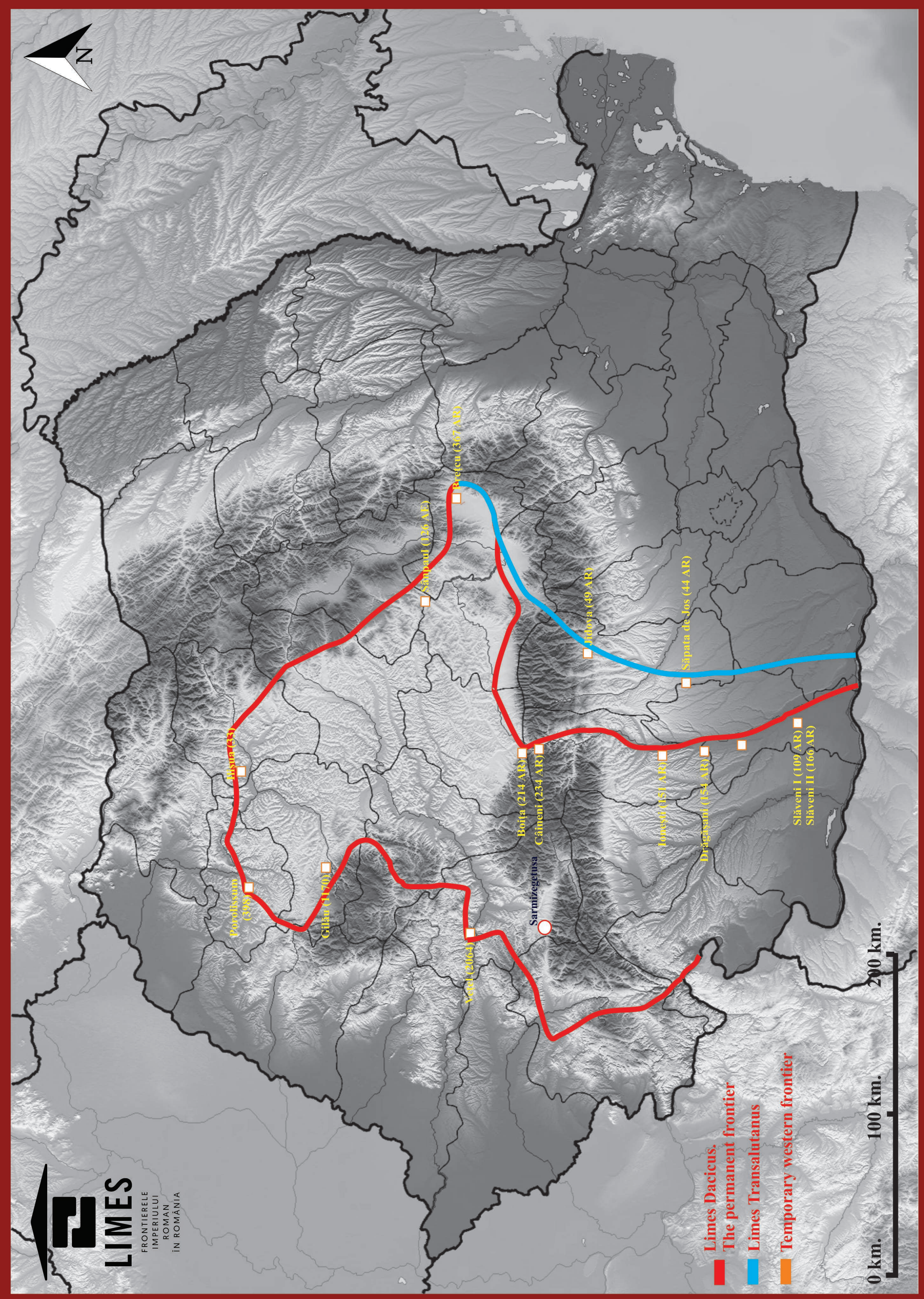

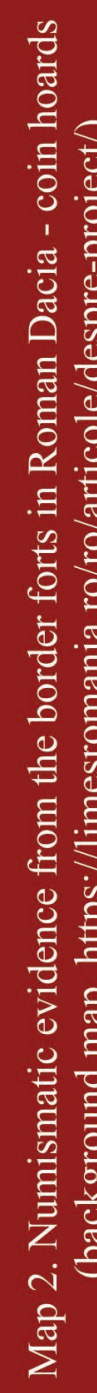




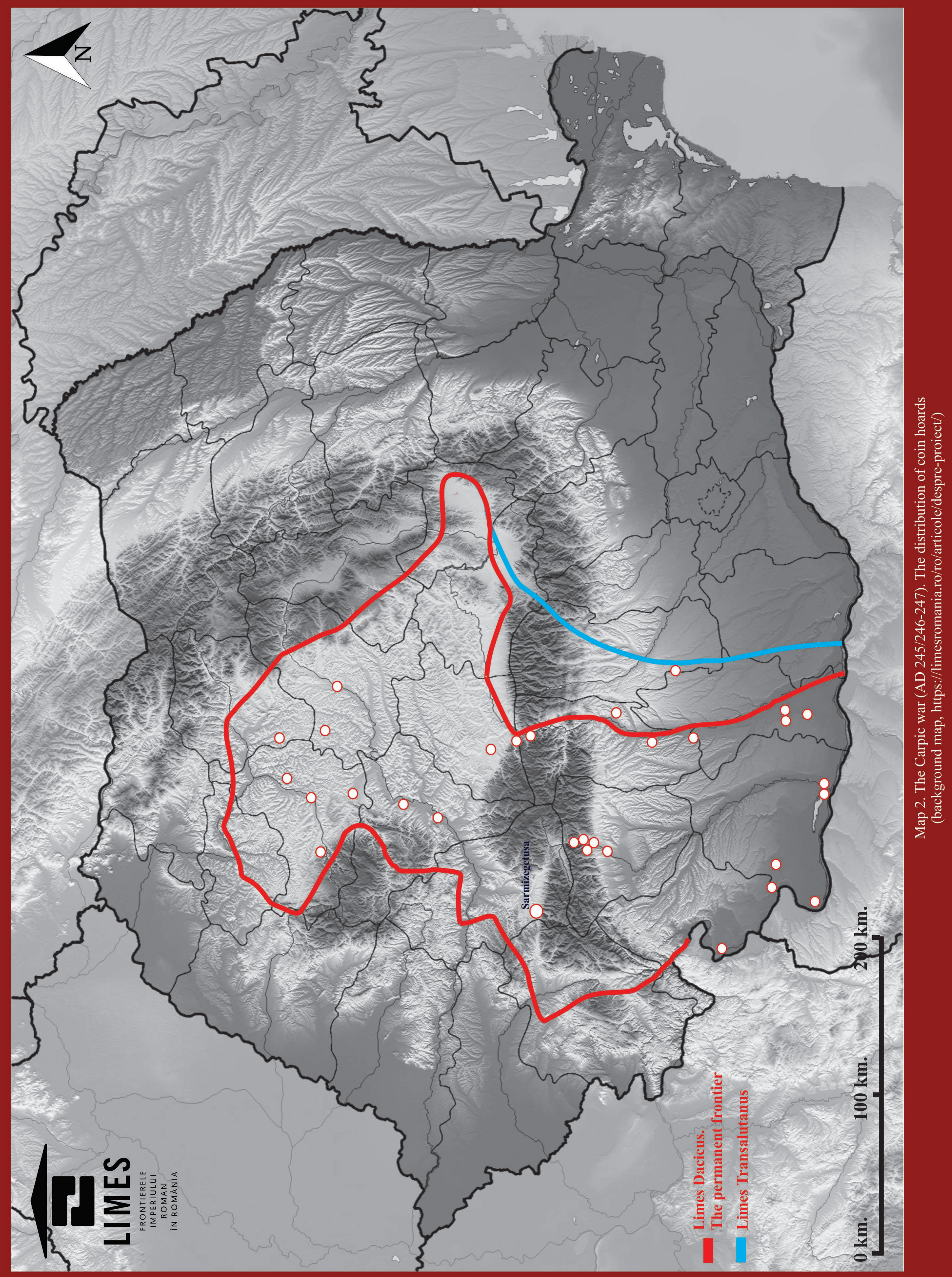

